Chumakov L.D., Mysov O.P., Savchenko M.O., Kravets V.I., Titova E.V.

\title{
EVALUATION OF CONTROL PERIODICITY OF OPERATIVE CONDITION OF TECHNICAL SYSTEM WITH THE «2 OF 3» SCHEME OF CHANNELS RESERVATION ON THE BASIS OF THE GIVEN VALUE OF EFFICIENCY
}

\author{
Ukrainian State University of Chemical Technology, Dnipro, Ukraine
}

\begin{abstract}
The paper discusses the issues of finding the duration of the interval between checks of the serviceable condition of technical systems with redundant channels according to the scheme « 2 of $3 »$ and «1 of $3 »$ when monitoring the health of the channels carried out according to the criterion of a set value of availability function. The influence of the degree of approximation of the objective function on the value of the interval between checks and the efficiency of using technical systems is investigated. The main task of designing equipment is to ensure a high level of its efficiency during operation. This is achieved both by constructive methods and by the choice of operational characteristics. In most cases, during the entire assigned lifetime, it is planned to carry out its maintenance in order to identify possible failures and restore an up state. In this case, there may be a latent failure in a certain set of parameters that determine the up state of the system. To eliminate it, the equipment is checked for operative condition. Different groups of parameters can be monitored continuously, periodically or not monitored throughout the assigned lifetime of the device. The article considers the case of periodic monitoring of an up state. One of the important operational characteristics of the equipment is the size of the interval between checks. The issues of determining the duration of the interval between checks of the up state of technical systems with redundant channels according to the « 2 of 3 » and «1 of 3 » schemes for monitoring the up state of the channels carried out according to the criterion of the set value of the availability factor are discussed. Channel operating time distribution is assumed to be exponential. An approximate solution to the problem consists in expanding the exponent for the availability factor in a row and finding the roots of the nonlinear equation. The analysis of the influence of the expansion terms number on the accuracy of solving the problem is carried out. Use of this method will reduce the number of checks compared to the optimal number.
\end{abstract}

Keywords: verification, technical system, reservation, frequency of control, fault assessment.

DOI: $10.32434 / 2521-6406-2019-6-2-97-102$

\section{Formulation of the problem and analysis of recent research and publications}

There is a large number of hazardous industries, including nuclear, chemical and biological objects of a particular danger, therefore the issue of their effective operation during the entire life cycle becomes urgent.

Modern technological systems include a large number of functionally interconnected technological equipment, which may result in failure of the entire system as a result of the failure.

To prevent the occurrence of emergency situations in the process of work and eliminate their consequences, special emergency systems are created.
Emergency systems in the process cycle are in a state of readiness to prevent and eliminate hazardous situations.

Periodically it is required to check their serviceability, which leads to certain losses in the implementation of the technological process.

In this regard, to ensure high efficiency of use of the technological system during the entire assigned service life, it is necessary to carry out its maintenance in order to identify possible failures and restore its operational status [1-6].

Main research material

One of the important operational characteristics of an emergency system is the value of the interval

(C) Chumakov L.D., Mysov O.P., Savchenko M.O., Kravets V.I., Titova E.V., 2019 
between checks.

To determine it, as a rule, the optimization problem is solved:

$$
\mathrm{K}_{\mathrm{af}}\left(\bar{\theta}^{*}\right)=\max _{\bar{\theta} \in \mathrm{R}} \mathrm{K}_{\mathrm{af}}(\bar{\theta}),
$$

where $\mathrm{K}_{\mathrm{af}}(\bar{\theta})$ is the availability factor; $\bar{\theta}$ is a set of intervals between checks; $\bar{\theta}^{*}$ is an optimal set of intervals between checks; $\mathrm{R}$ is the area that defines the set of valid control strategies.

Usually, the curve of dependence of availability factors on the magnitude of the interval between checks in the optimum area has a smooth form and, therefore, the number of checks can be reduced from the condition that the requirements for availability are met.

Then the selection condition for the quantity $\theta^{*}$ has the form:

$$
\mathrm{K}_{\mathrm{af}}\left(\theta^{*}\right)=\mathrm{K}_{\mathrm{af}}^{\mathrm{g}},
$$

where $\theta^{*}$ is the set of intervals between checks when the above condition is met; $\mathrm{K}_{\mathrm{af}}^{\mathrm{g}}$ is the set value of the availability factor.

In this article, technical systems are considered that are in a state of readiness to accomplish their task on an interval $[0, \mathrm{~T}]$, where $\mathrm{T}$ is the designated useful life.

At a random moment of time, evenly distributed over the interval $[0, \mathrm{~T}]$, a command may be received to use a technical system. In this case, there may be a hidden failure according to some set of parameters that determine the performance of a system. To eliminate it, checks are performed on a technical system. Different groups of parameters can be monitored continuously, periodically or not monitored over the entire life cycle.

Let the up state of one channel of a system with a reserve be distributed according to the exponential law $\mathrm{F}(\mathrm{t})=1-\mathrm{e}^{-\mathrm{tt}}$ where 1 is the intensity of its failures.

If we assume that the replacement time is insignificant, the expression for the availability factor for redundancy according to the «2 out of 3 » scheme can be written as follows:

$\mathrm{K}_{\mathrm{af}}(\theta)=\frac{\frac{3}{2}\left(1-\mathrm{e}^{-2 \lambda \theta}\right)-\frac{2}{3}\left(1-\mathrm{e}^{-3 \lambda \theta}\right)}{\lambda(\theta+\tau)}$,

where $\theta$ is a value of the interval between checks; $\tau$ is check duration.

An approximate solution of the problem can be searched for by decomposition of exponents in the expression (1) in a row and taking different numbers of expansion terms.

Formula (1) will have a following form: for 3 expansion members:

$\mathrm{K}_{\mathrm{af}}(\theta) \approx\left(\theta-\lambda^{2} \theta^{3}\right) /(\theta+\tau)$

for 4 expansion members:

$$
\mathrm{K}_{\mathrm{af}}(\theta) \approx \frac{\theta-\lambda^{2} \theta^{3}+\frac{5}{4} \lambda^{3} \theta^{4}}{\theta+\tau}
$$

for 5 expansion members:

$$
\mathrm{K}_{\mathrm{af}}(\theta) \approx \frac{\theta-\lambda^{2} \theta^{3}+\frac{5}{4} \lambda^{3} \theta^{4}-\frac{19}{20} \lambda^{4} \theta^{5}}{\theta+\tau} .
$$

Let's the channel of the system consist of one computer with a failure rate of $\lambda=0.8649 \mathrm{Y}^{-1}$. The check time of the system is $\tau=0.0044 \mathrm{Y}$ [7]. With an optimal control strategy, $\mathrm{K}_{\mathrm{af}}^{\mathrm{opt}}=0.9176$. If it is required to ensure $\mathrm{K}_{\mathrm{af}}^{\mathrm{g}}=0.95$, then, in this case, it is necessary to apply channel redundancy, for example, with reservation of channels on the scheme of $\ll 2$ of $3 »$.

We investigate the dependence of the system efficiency on the control strategy.

The graphs of the dependence of the system availability factor on the length of the intervals between checks, built on the basis of the formulas (1-4) are shown in fig. 1.

We write expressions for equations, from which it is possible to calculate the value of the interval between checks.

Using expression (2), we obtain the following equation:

$\lambda^{2} \theta^{3}-\left(1-\mathrm{K}_{\mathrm{af}}^{\mathrm{g}}\right) \theta+\mathrm{K}_{\mathrm{af}}^{\mathrm{g}} \tau=0$.

If we use the expression (3), then the equation will have the following form:

$\frac{5}{4} \lambda^{3} \theta^{4}-\lambda^{2} \theta^{3}+\left(1-\mathrm{K}_{\mathrm{af}}^{\mathrm{g}}\right) \theta-\mathrm{K}_{\mathrm{af}}^{\mathrm{g}} \tau=0$,

Transforming the expression (4), we obtain the equation of the 5 th degree:

$\frac{19}{20} \lambda^{4} \theta^{5}-\frac{5}{4} \lambda^{3} \theta^{4}+\lambda^{2} \theta^{3}-$

$-\left(1-\mathrm{K}_{\mathrm{af}}^{\mathrm{g}}\right) \theta+\mathrm{K}_{\mathrm{af}}^{\mathrm{g}} \tau=0$. 


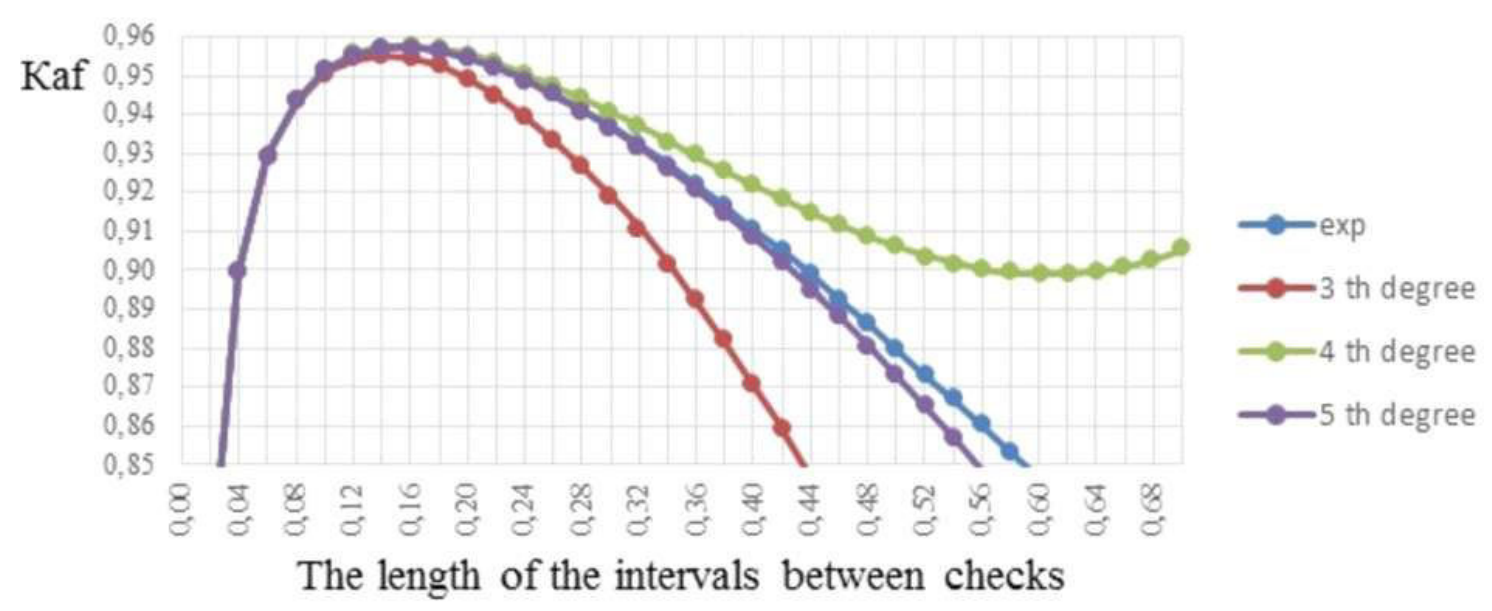

Fig. 1. Dependence of availability factor on the intervals between checks

The solution of such equations causes certain difficulties; however, algorithms have been developed that makes it possible to find their solutions [8]. The best approximate solutions are obtained by using the expression (7).

Let's us estimate the values of the desired and optimal inspection intervals for our example (table 1).

Table 1

Values of inspection intervals and availability factors

\begin{tabular}{l|c|c|c|c|c}
\hline The equation & $\theta^{*} \mathrm{Y}$ & $\theta^{\text {opt }} \mathrm{Y}$ & $\mathrm{K}^{\mathrm{af}}\left(\theta^{*}\right)$ & $\mathrm{K}^{\mathrm{af}}\left(\theta^{\mathrm{opt}}\right)$ & $\theta^{*} / \theta^{\mathrm{opt}}$ \\
\hline Exponents & 0.235 & 0.15 & 0.9499 & 0.9576 & 1.57 \\
\hline 3rd degree & 0.196 & 0.14 & 0.9499 & 0.9553 & 1.4 \\
\hline 4th degree & 0.244 & 0.16 & 0.95 & 0.9578 & 1.53 \\
\hline 5th degree & 0.234 & 0.15 & 0.9499 & 0.9575 & 1.56 \\
\hline
\end{tabular}

If it is required to ensure $\mathrm{K}_{\mathrm{af}}^{\mathrm{g}}=0.98$, then, in this case, it is necessary to apply channel redundancy according to the «1 of 3 » scheme.

Consider a system with redundancy «1 of $3 »$.

Expression for availability:

$$
\begin{aligned}
& \mathrm{K}_{\mathrm{af}}(\theta)=\frac{18\left(1-\mathrm{e}^{-\lambda \theta}\right)-9\left(1-\mathrm{e}^{-2 \lambda \theta}\right)}{6 \lambda(\theta+\tau)}+ \\
& +\frac{2\left(1-\mathrm{e}^{-3 \lambda \theta}\right)}{6 \lambda(\theta+\tau)} .
\end{aligned}
$$

By decomposing the exponents in expression (8) in a row and taking different numbers of expansion terms, we get:

for 2-members expansion:

$$
\mathrm{K}_{\mathrm{af}}(\theta) \approx\left(\theta-\frac{1}{4} \lambda^{3} \theta^{4}\right) /(\theta+\tau)
$$

for 3 expansion members:

$\mathrm{K}_{\mathrm{af}}(\theta) \approx \frac{\theta-\frac{1}{4} \lambda^{3} \theta^{4}+\frac{3}{10} \lambda^{4} \theta^{5}}{\theta+\tau}$

for 4 expansion members:

$\mathrm{K}_{\mathrm{af}}(\theta) \approx \frac{\theta-\frac{1}{4} \lambda^{3} \theta^{4}+\frac{3}{10} \lambda^{4} \theta^{5}-\frac{5}{24} \lambda^{5} \theta^{6}}{\theta+\tau}$

for 5 expansion members:

$$
\begin{aligned}
& \mathrm{K}_{\mathrm{af}}(\theta) \approx \frac{1}{\theta+\tau}\left(\theta-\frac{1}{4} \lambda^{3} \theta^{4}+\frac{3}{10} \lambda^{4} \theta^{5}-\right. \\
& \left.-\frac{5}{24} \lambda^{5} \theta^{6}+\frac{3}{28} \lambda^{6} \theta^{7}\right)
\end{aligned}
$$

The graphs of the dependence of the system availability factor on the value of the interval between inspections, built on the basis of the formulas (912) are shown in Fig. 2.

Using expression (9), we obtain the following equation:

$\lambda^{3} \theta^{4}-4\left(1-\mathrm{K}_{\mathrm{af}}^{\mathrm{g}}\right) \theta+\mathrm{K}_{\mathrm{af}}^{\mathrm{g}} \tau=0$.

If we use the expression (10), then the equation will have the following form:

$$
\begin{aligned}
& 12 \lambda^{4} \theta^{5}-10 \lambda^{3} \theta^{4}+40\left(1-\mathrm{K}_{\mathrm{af}}^{\mathrm{g}}\right) \theta- \\
& -40 \mathrm{~K}_{\mathrm{af}}^{\mathrm{g}} \tau=0 .
\end{aligned}
$$




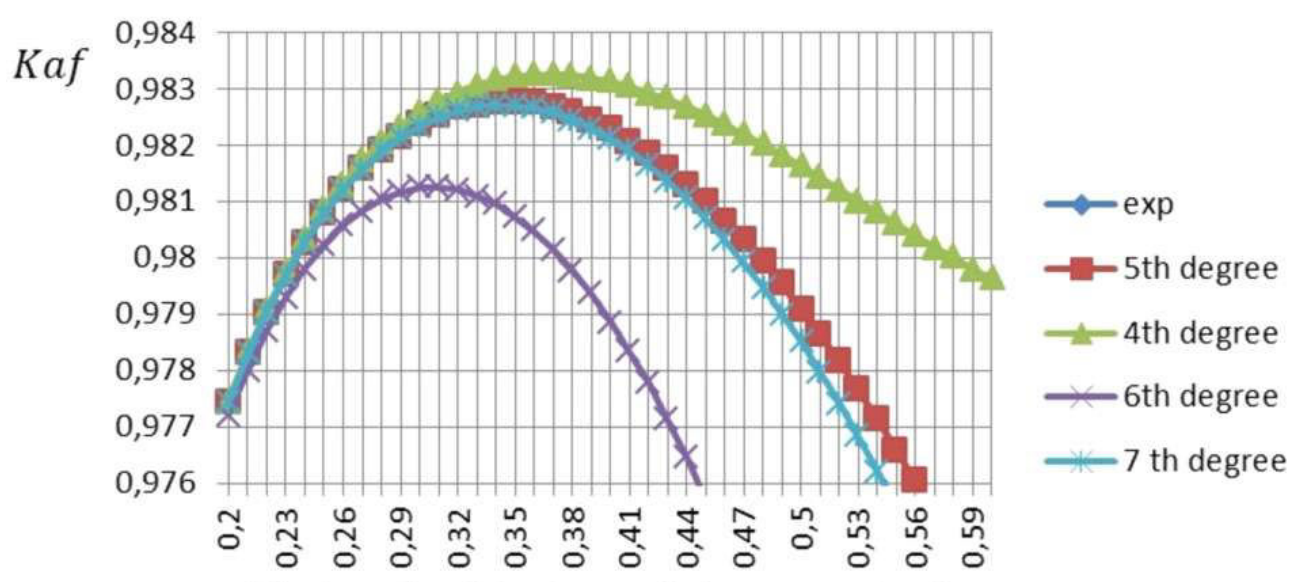

The length of the intervals between checks

Fig. 2. Dependence of availability factor on the value of the interval between checks for the «1 of $3 »$ scheme

And, transforming the expression (11), we obtain the equation of the 6th degree:

$$
\begin{aligned}
& 111 \lambda^{5} \theta^{6}-216 \lambda^{4} \theta^{5}+180 \lambda^{3} \theta^{4}- \\
& -720\left(1-\mathrm{K}_{\mathrm{af}}^{\mathrm{g}}\right) \theta+720 \mathrm{~K}_{\mathrm{af}}^{\mathrm{g}} \tau=0 .
\end{aligned}
$$

From the expression (12), follows:

$$
\begin{aligned}
& 4247 \lambda^{6} \theta^{7}-777 \lambda^{5} \theta^{6}+1512 \lambda^{4} \theta^{5}- \\
& -1260 \lambda^{3} \theta^{4}+5040\left(1-\mathrm{K}_{\mathrm{af}}^{\mathrm{g}}\right) \theta- \\
& -5040 \mathrm{~K}_{\mathrm{af}}^{\mathrm{g}} \tau=0 .
\end{aligned}
$$

Values of inspection intervals and availability factors are shown in table 2.

Table 2

\section{Values of inspection intervals and availability factors}

\begin{tabular}{l|c|c|c|c|c}
\hline The equation & $\theta^{*} \mathrm{Y}$ & $\theta^{\text {opt }} \mathrm{Y}$ & $\mathrm{K}^{\text {af }}\left(\theta^{*}\right)$ & $\mathrm{K}^{\text {af }}\left(\theta^{\text {opt }}\right)$ & $\theta^{*} / \theta^{\text {opt }}$ \\
\hline The equation & $\theta^{*} \mathrm{Y}$ & $\theta^{\text {opt }} \mathrm{Y}$ & $\mathrm{K}^{\text {af }}\left(\theta^{*}\right)$ & $\mathrm{K}^{\text {af }}\left(\theta^{\text {opt }}\right)$ & $\theta^{*} / \theta^{\text {opt }}$ \\
\hline Exponents & 0.235 & 0.15 & 0.9499 & 0.9576 & 1.57 \\
\hline 3rd degree & 0.196 & 0.14 & 0.9499 & 0.9553 & 1.4 \\
\hline 4th degree & 0.244 & 0.16 & 0.95 & 0.9578 & 1.53 \\
\hline 5th degree & 0.234 & 0.15 & 0.9499 & 0.9575 & 1.56 \\
\hline
\end{tabular}

\section{Conclusions}

Thus, refusal to assign the optimal values of the intervals between checks and the use of intervals that provide a given level of readiness can reduce the number of checks and the operation cost.

Studies have been carried out to determine the interval between inspections of the technical system with redundancy according to the «2 of 3» and «1 of 3 » scheme from the condition of meeting the requirements for its effectiveness.

It is shown that this approach can reduce the number of checks compared to the optimal strategy and provide an economic effect.

\section{REFERENCES}

1. Волик Б.Г. Работоспособность управляющих систем. Датчики и системы. - 2010. - № 5. - С.75-78.

2. Гнеденко Б.В., Беляев Ю.К., Соловьев А.Д. Математические методы в теории надежности: Основные характеристики надежности и их статистический анализ. Изд.2. - М.: URSS, 2013. $-584 \mathrm{c}$.

3. Черкесов Г.Н. Надежность аппаратно-программных комплексов: учеб, пособие. - СПб.: Питер, 2005. - 479 с.

4. Шубинский И.Б. Функциональная надежность информационных систем: методы анализа. - Ульяновск : Надежность, 2012. - 297 с.

5. Сердаков А.С. Автоматический контроль и техническая диагностика. - Киев: Техника, 1971. - 244 с.

6. Пархоменко П.П., Согомонян Е.С. Основы технической диагностики / Под ред. П.П. Пархоменко. - М.: Энергия, 1981. $-320 \mathrm{c}$.

7. Chumakov L.D. Selection of strategy of control of good state of technical system with duplication of channels and verification of their good state on the basis of given value of efficiency, System technologies. - Vol.4(123). - Dnipro. - 2019. - P.106-111. https://doi.org/10.34185/1562-9945-4-123-2019-11

8. Calculation of the roots of a polynomial [Electronic resource]: Electronic data., Access Mode: www.wolframalpha.com, free, The title from the screen.

Received 15.11.2019

Chumakov L.D., Mysov O.P., Savchenko M.O., Kravets V.I., Titova E.V. 


\section{ОЦІНКА ПЕРІОДИЧНОСТІ КОНТРОЛЮ СПРАВНОГО СТАНУ ТЕХНІЧНОЇ СИСТЕМИ ЗА СХЕМОЮ РЕЗЕРВУВАННЯ КАНАЛІВ «2 3 3» НА ОСНОВІ ЗАДАНОГО ЗНАЧЕННЯ ЕФЕКТИВНОСТІ}

\section{Чумаков Л.Д., Мисов О.П., Савченко М.О., Кравець В.І., Тітова O.B.}

В статті обговорюються питання знаходження тривалості інтервалу між перевірками справного стану технічних систем з резервуванням каналів за схемою «2 з 3-x» $i$ 《 3 3-х» при здійсненні контролю справності каналів за критерієм заданої величини коефіцієнта готовності. Досліджено вплив ступеня наближення цільової функцї на величину інтервалу між перевірками і ефективність використання технічних систем. Основним завданням проектування обладнання є забезпечення високого рівня його ефективності в процесі експлуатації. Це досягається як конструктивними методами, так $і$ вибором експлуатаційних характеристик. У більшості випадків протягом усього призначеного терміну експлуатації планується виконувати його обслуговування з метою виявлення можливих збоӥв і відновлення стану. У иьому випадку може статися прихований збій у певному наборі параметрів, що визначають стан роботи системи. Для його усунення обладнання перевіряється на справний стан. Різні групи параметрів можуть відслідковуватися постійно, періодично або не контролюватися протягом відведеного терміну експлуатації пристрою. У статті розглядається випадок періодичного моніторингу стану. Однією з важливих експлуатаційних характеристик обладнання є розмір інтервалу між перевірками. Питання визначення тривалості інтервалу між перевірками стану технічних систем із надлишковими каналами за схемами «2 з 3» та «1 3 3» для моніторингу стану каналів, шо здійснюються за критерієм заданого значення коефіцієнта доступності обговорюються. Розподіл часу роботи каналу вважається експоненціальним. Наближене рішення задачі полягає у розширенні показника для коефіцієнта доступності підряд і пошуку коренів нелінійного рівняння. Виконано аналіз впливу на точність вирішення задачі про кількість термінів розширення. Використання цього методу зменшить кількість перевірок порівняно з оптимальною кількістю.

Ключові слова: повірка, технічна система, резервування, періодичність контролю, оцінювання несправності.

\section{ОЦЕНКА ПЕРИОДИЧНОСТИ КОНТРОЛЯ ИСПРАВНОГО СОСТОЯНИЯ ТЕХНИЧЕСКОЙ СИСТЕМЫ ПО СХЕМЕ РЕЗЕРВИРОВАНИЯ КАНАЛОВ «2 ИЗ 3» НА ОСНОВЕ ЗАДАННОГО ЗНАЧЕНИЯ ЭФФЕКТИВНОСТИ}

Чумаков Л.Д., Мысов О.П., Савченко М.О., Кравец В.И., Tumoва E.B.

В статье обсуждаются вопросы нахождения длительности интервала между проверками исправного состояния технических систем с резервированием каналов по схеме «2 из 3-x» $и$ «1 из 3-x» при осуществлении контроля исправности каналов по критерию заданной величины коэффициента готовности. Исследовано влияние степени приближения целевой функции на величину интервала между проверками и эффективность использования технических систем. Основной задачей проектирования оборудования является обеспечение высокого уровня его эффективности при эксплуатации. Это достигается как конструктивными методами, так и выбором эксплуатационных характеристик. В большинстве случаев в течение всего назначенного срока службы планируется проводить техническое обслуживание, чтобы выявить возможные сбоя и восстановить работоспособное состояние. В этом случае возможен скрытый сбой в определенном наборе параметров, которые определяют состояние системы. Чтобы устранить это, оборудование проверяется на исправность. Различные группы параметров могут отслеживаться непрерывно, периодически или не контролироваться в течение всего назначенного срока службы устройства. В статье рассмотрен случай периодического мониторинга работоспособного состояния. Одной из важных эксплуатационных характеристик оборудования является величина интервала между проверками. Вопросы определения продолжительности интервала между проверками работоспособного состояния технических систем с резервными каналами по схемам «2 из 3» $и$ «1 из 3» для мониторинга работоспособного состояния каналов, выполняемых по критерию установленного значения коэффициента доступности. Распределение времени работы канала предполагается экспоненциальным. Приближенное решение задачи состоит в увеличении показателя степени для коэффициента доступности в ряд и нахождении корней нелинейного уравнения. Проведен анализ влияния на точность решения задачи числа членов разложения. Использование этого метода уменьшит количество проверок по сравнению с оптимальным количеством.

Ключевые слова: поверка, техническая система, резервирование, периодичность контроля, оценка неисправности.

\section{EVALUATION OF CONTROL PERIODICITY OF OPERATIVE CONDITION OF TECHNICAL SYSTEM WITH THE «2 OF 3» SCHEME OF CHANNELS RESERVATION ON THE BASIS OF THE GIVEN VALUE OF EFFICIENCY}

Chumakov L.D., Mysov O.P., Savchenko M.O., Kravets V.I., Titova E.V.

Ukrainian State University of Chemical Technology, Dnipro, Ukraine

The paper discusses the issues of finding the duration of the interval between checks of the serviceable condition of technical systems with redundant channels according to the scheme "2 of 3» and «1 of 3» when monitoring the health of the channels carried out according to the criterion of a set value of availability function. The influence of the degree of approximation of the objective function on the value of the interval between checks and the efficiency of using technical systems is investigated. The main task of designing equipment is to ensure a high level of its efficiency during operation. This is achieved both by constructive methods and by the choice of operational characteristics. In most cases, during the entire assigned lifetime, it is planned to carry out its maintenance in order to identify possible failures and restore an up state. In this case, there may be a latent failure in a certain set of parameters that determine the up state of the system. To eliminate it, the equipment is checked for operative condition. Different groups of parameters can be monitored continuously, periodically or not monitored throughout the assigned lifetime of the device. The article considers the case of periodic monitoring of an up state. One of the important operational characteristics of the equipment is the size of the interval between checks. The issues of determining the duration of the interval between checks of the up state of technical systems with redundant channels according to the «2 of $3 »$ and «1 of 3» schemes for monitoring the up state of the channels carried out according to the criterion of the set value of the availability factor are discussed. Channel operating time distribution is assumed to be exponential. An approximate solution to the problem consists in expanding the exponent for the availability factor in a row and finding the roots of the nonlinear equation. The analysis of the influence of the expansion terms number on the accuracy of solving the problem is carried out. Use of this method 
will reduce the number of checks compared to the optimal number.

Keywords: verification, technical system, reservation, frequency of control, fault assessment.

\section{REFERENCES}

1. Volik B.G. Rabotosposobnost' upravlyayushchikh sistem. Datchiki $i$ sistemy [The performance of control systems. Sensors and Systems], no. 5, 2010, pp.75-78 (in Russian).

2. Gnedenko B.V., Belyayev Yu.K., Solov'yev A.D. Matematicheskiye metody $v$ teorii nadezhnosti: Osnovnyye kharakteristiki nadezhnosti i ikh statisticheskiy analiz [Mathematical methods in the theory of reliability: The main characteristics of reliability and their statistical analysis]. vol. 2, Moskow, URSS, 2013, 584 p. (in Russian).

3. Cherkesov G.N. Nadezhnost' apparatno-programmnykh kompleksov [Reliability of hardware and software systems]. Textbook, manual., St. Petersburg: Peter, 2005, 479 p. (in Russian).

4. Shubinskiy I.B. Funktsional'naya nadezhnost' informatsionnykh sistem: metody analiza [Functional reliability of information systems: analysis methods]. Reliability, Ulyanovsk, 2012, 297 p. (in Russian).

5. Serdakov A.S. Avtomaticheskiy kontrol' i tekhnicheskaya diagnostika [Automatic control and technical diagnostics]. Technique, Kiev, 1971, 244 p. (in Russian).

6. Parkhomenko P.P., Soghomonyan E.S. Osnovy tekhnicheskoy diagnostiki [Fundamentals of technical diagnostics], Ed. P.P. Parkhomenko. Moskow, Energy, 1981, 320 p. (in Russian).

7. Chumakov L.D. Selection of strategy of control of good state of technical system with duplication of channels and verification of their good state on the basis of given value of efficiency, System technologies, 4(123), Dnipro, 2019, pp.106-111. https://doi.org/10.34185/1562-9945-4-123-2019-11.

8. Calculation of the roots of a polynomial [Electronic resource]: Electronic data, Access Mode: www.wolframalpha.com, free, The title from the screen.

Chumakov L.D., Mysov O.P., Savchenko M.O., Kravets V.I., Titova E.V. 